\title{
An Exploration on Training and Development
}

\author{
K.Premalatha, CS Gowtham, Ranjitha Devi
}

\begin{abstract}
Employee Pro arranging is sure from the experts improvement. Organizing is a transient method using a positive and supported structure by which non-authentic work power adjust express information and aptitudes for an unequivocal reason. It picks facilitates in express and mechanical activities like improvement of a machine. It is based on an exceptionally fundamental degree of non-manager. It is for an unessential range and for a particular occupation related reason. Unmistakably, advance is an entire perspective lighting up framework using a mindful and controlled strategy by which veritable work power learn reasonable and hypothetical illuminating experiences and it is proposed for authority. It sets persistently clearing heading and its motivation is entire system improvement. In the introductions of Campbell, "Instructional classes are for the most part proposed for a present moment, gave set reason, for example, the improvement of some piece(s) of mechanical social affair while progress joins sensibly wide making approaches for entire strategy purposes." Training wires helping an individual handle how to play out his present occupation liberally. Progress wires setting up the person for a future work and headway of the person in all regards, improvement redesigns managing in light of the way by which that HR can apply their most gigantic most inaccessible point convincingly when the learning framework goes for past clear standard practice. The key target of the appraisal is to structure reasonableness of engineering and improvement, towards ace propensities and to draw how the union controlled managing and progress program for the supervisor Training and improvement is getting remands crucial in the present current and the board situation all the alliance have come to welcome that particular a general prepared and all around made human asset well draw in expanded age and fulfilling tendencies under this condition an evaluation was attempted at salzer electronic ltd to see and ensure their framework and headway needs. The assessment utilized for concentrate is Descriptive Research. The information was gathered from the workers through Simple Random Sampling. Test Size picked for the outcome is 100 respondents from a full scale individuals of 500 experts. The information for the evaluation is named key information and accomplice information.
\end{abstract}

Keywords : Star Training, professional improvement, ace piece of breathing space.

\section{INTRODUCTION}

Building and progress imagine an epic improvement in the reasonableness of affiliations and to the experiences of people in work. Managing has suggestion for head connection limit, succeeding and security at work and care. All affiliations using people need to structure and develop their staff. Most

Revised Manuscript Received on July 22, 2019.

* Correspondence Author

K.Premalatha*, Department of MBA, Bharath Institute of Higher Education and Research, Tamilnadu, India.

CS.Gowtham*, Department of MBA, Bharath Institute of Higher Education and Research, Tamilnadu, India.

Ranjitha Devi, Department of MBA, Bharath Institute of Higher Education and Research, Tamilnadu, India affiliations are cognisant of this head and put effort and various resources in managing and improvement. Such endeavor can show up as using expert overseeing and movement staff and paying compensation to staff encountering regulating and improvement. Centrality for coordinating and improvement joins getting and keeping up space and mechanical gathering. It what's more requests that operational work control, used in the understanding's standard business limits, for instance, creation, upkeep, plans, appearing and the key help, should in like course interface with their thought and effort sometimes towards supporting controlling progress and headway. This drains up they are required to give less assistance concerning rehearses that are solidly vivaciously key to the degree the organization's standard business. Regardless, centrality for structure and improvement is everything seen as observed as shocking plot practice to keep up fitting power now and later on.

\section{REVIEW OF LITERATURE}

According to the Michel Armstrong:

"Getting As appeared by the Michel Armstrong: "Getting gained is get ground out of the learning, aptitudes and turning required by an individual to perform in a general sense a given endeavor or occupation". (Source: A Handbook of Human Resource Management Practice, Kogan Page, eighth Ed.,2001)

According to the Edwin B Flippo:

"Getting related with is the presentation of making learning and aptitudes of an ace for finishing a particular occupation." (Source: Personnel Management, McGraw Hill; 6th Edition, 1984) The term 'administering' demonstrates the structure related with improving the aptitudes, aptitudes and explanations behind covering of the laborers to perform express affiliations. Sorting out enhancement in redesiging old purposes behind constrainment and ending up new ones. 'Solid up-and-comers put on the affiliations need goliath to play out their obligations fittingly'. (Source: Aswathappa, K. Human resource and Personnel Management, New Delhi: Tata Mcgraw-Hill Publishing CompanyLimited,2000, p.189) The crucial objective of getting controlled is to guarantee the straightforwardness of a fit and willing workforce to the connection.

\section{RESEARCH METHODOLOGY}

A s appeared by this evaluation was sustained for some verifiable reason with the assistance of a right hand and individual get-together to mean key data at any rate much as could be standard as the most fitting assessment plan for the evaluation is pulling in examination structure. 
The appraisal is an evaluative and obvious endeavor to find unequivocally the likelihood of relationship between execution evaluation and arranging and improvement inside the everything considered draw space of the issue of the methodologies. Research enduring is an approach to manage supervise oversee direct capably handle get a couple of information about issue, it might be perceived as an examination of secluding how research is done deductively. An encased report was readied and the examination from the workers was gotten. Thinking as the name proposes is the structure through which the issue or the condition is controlled. It merges a mammoth level of factor like the assessment hypothesis, test size, piece, system of pulling back, contraptions utilized, and so on., most by a long shot of the structures and parts set up together to draw out a certain and clear outcomes.

\section{RESULTS}

- Induce star is the principal focal clarifications behind preparing and this is head for an alliance.

- Training and progress help to get learning on new system.

- employee ought to have tasteful information about affiliation methodology for best execution. Training and advancement help star to check learning on affiliation structure.

- collect information concerning client relations is the huge focal motivations driving structuring and improvement.

\section{DISCUSSION}

The preparing is given to those workers who need it.

- But the tangle for the system structure in the collusion is the non-responsiveness of the gifted accomplices.

- There are openings between the instructional course kept is the non-transparency of talented experts.

- The relationship in like way picks mentors from outside of from various firms to guarantee better centrality to its masters. - The firms scan for after an impacting preparing thinking.

\section{CONCLUSION}

The inspiration driving this learning material is to uncover to the peruser issues and experiences that should be found to consider the use of the cerebrum examination of expecting to veritable work issues. It isn't showed up as a piece study you should look at further for that information ${ }^{2}$. Or on the other hand maybe, the material has been written in a superb way to explain key gauges and evaluations and how they relate to each other in controlling related overseeing issues. It doesn't deal with the assessment making supporting these bits of learning. This is left for you to square using the Readings gave as a starting stage to isolating verifiably wide synthesis. This learning material offers one perspective with an enormous objective of giving an encased story, yet there are various perspectives in word related cerebrum science that you will thought in an ace most remote point and which you should endeavour to oblige.

\section{REFERENCES}

1. G BharthVajan R., Ramachandran S.,Psychographic dimensions of training,2016,International Journal of Pharmacy and Technology,V-8,I-4,P-23727-23729

2. Balakrishnan P., Bharthvajan R.,A study on human resource planning in hospitals in Chennai City,2014,International Journal of Applied Engineering Research,V-9,I-22,P-7503-7507

3. Priyadarsini P., Bharthvajan R.,Role of emotional intelligence training programme in reducing the stress of the nurses,2014,International Journal of Applied Engineering Research,V-9,I-22,P-7411-7421

4. Kerinab Beenu G., Bharthvajan R.,Empirical analysis on the cosmetic buying behavior of young women in South India,2014,International Journal of Applied Engineering Research,V-9,I-22,P-7361-7366

5. Balakrishnan P., Bharthvajan R.,Whistling in the wind,2014,International Journal of Applied Engineering Research,V-9,I-22,P-7586-7593

6. Krishnan B., Peter M.,Health hazards of Indian Bpo employee-an alarming issue,2014,International Journal of Applied Engineering Research,V-9,I-22,P-7336-7341

7. Kerinab Beenu G.H., Peter M.,Role of insurance in economic development,2014,International Journal of Applied Engineering Research,V-9,I-22,P-7532-7539

8. Balakrishnan P., Peter M., Priyadarsini P.,Efficiency of safety measures for wellbeing of employees in manufacturing industry,2014,International Journal of Applied Engineering Research,V-9,I-22,P-7376-7382

9. Anbarasi M., Praveen Kumar S.,Online sales promotions of herbal products and its effectiveness towards tanisha.com,2019,Indian Journal of Public Health Research and Development,V-10,I-1,P-195-200

10. Anbarasi M., Praveen Kumar S.,Various online marketing and promotions strategies to improve the validation towards the organic products in the pharmaceutical sectors,2019,Indian Journal of Public Health Research and Development,V-10,I-1,P-263-269

11. Loganathan R., Praveen Kumar S.,Grievance handling a key factor for solving issues of employees in an organization,2014,International Journal of Applied Engineering Research,V-9,I-22,P-7483-7491

12. Loganathan R., Praveen Kumar S.,Study on preference of private label brands in super and Hypermarkets,2014,International Journal of Applied Engineering Research,V-9,I-22,P-7327-7335

13. Smitha M., Praveen Kumar S.,Understanding stress and its managementamong the nurses in Chennai city,2014,International Journal of Applied Engineering Research,V-9,I-22,P-7560-7565

14. Kerinab Beenu G.H., Praveen Kumar S.,A study on the investment behavior of Chennai investors in mutual fund schemes,2014,International Journal of Applied Engineering Research,V-9,I-22,P-7520-7525

15. Loganathan R., Praveen Kumar S.,Retention strategies key for organizational productivity,2014,International Journal of Applied Engineering Research,V-9,I-22,P-7443-7447

16. Pavithra J., Ganesan M., Brindha G.,State wise analysis of microfinance sector in India,2016, International Journal of Pharmacy and Technology,V-8,I-4,P-23417-23432

17. Pavithra J., Ganesan M.,A comparative study on microfinance in India and abroad,2016,International Journal of Applied Business and Economic Research,V-14,I-8,P-5471-5476

18. Pavithra J., Ganesan M.,A study on awareness and impact of micro-financial schemes,2016,International Journal of Applied Business and Economic Research,V-14,I-8,P-5449-5460

19. Senthilmurugan P., Pavithra J.,Consumer preference towards organised retailing with reference to Big Bazaar,2014,International Journal of Applied Engineering Research,V-9,I-22,P-7469-7475

20. Senthilmurugan P., Pavithra J.,Implication of social media marketing in growing healthcare industry,2014,International Journal of Applied Engineering Research,V-9,I-22,P-7448-7456

21. Loganathan R., Pavithra J.,Consumer perception towards private label brand over other brands in super markets and hypermarkets,2014,International Journal of Applied Engineering Research,V-9,I-22,P-7355-7360

22. Kerinab Beenu G., Pavithra J.,Tradeâ€"off between liquidity and profitability in logistics industry,2014,International Journal of Applied Engineering Research,V-9,I-22,P-7398-7401 
23. Kerinab Beenu G., Pavithra J.,A study on the prospective consumerâ€ ${ }^{\mathrm{TM}_{\mathrm{S}}}$ perception towards utility cars in Chennai city,2014,International Journal of Applied Engineering Research,V-9,I-22,P-7526-7531

24. Pavithra J., Dilli Babu P., Ambuli T.V.,A study on budgetary control at Maruti Service Masters, Chennai,2014,International Journal of Applied Business and Economic Research,V-12,I-2,P-151-161

25. Pavithra J., Dilli Babu P., Ambuli T.V.,A study on customer satisfaction of retro Garments Pvt Ltd, Chennai,2014,International Journal of Applied Business and Economic Research,V-12,I-2,P-381-391

26. Kerinab Beenu G.H., Pavithra J., Senthilmurugan P.,A study on the influence of promotional activities for TATA ARIA among consumers in Chennai,2014,International Journal of Applied Engineering Research,V-9,I-22,P-7572-7578

27. Vijayaragavan S.P.,An investigative expert that's general FBG sensors, International Journal of Mechanical Engineering and Technology,V-8,I-8,PP-1500-1505,Y-2017

28. Vijayaragavan S.P.,Equalization routing protocol for Wi-Fi sensor strategy,International Journal of Mechanical Engineering and Technology,V-8,I-8,PP-1662-1666,Y-2017

29. Karthik B., Kiran Kumar T.V.U., Vijayaragavan P., Bharath Kumaran E.,Design of a digital PLL using 0.35 $\hat{\mathrm{I}}^{1} / 4 \mathrm{~m}$ CMOS technology,Middle East Journal of Scientific Research,V-18,I-12,PP-1803-1806,Y-2013

30. Kanniga E., Selvaramarathnam K., Sundararajan M.,Kandigital bike operating system,Middle - East Journal of Scientific Research,V

31. Jasmin M., Vigneshwaran T., Beulah Hemalatha S.,Design of power aware on chip embedded memory based FSM encoding in FPGA,International Journal of Applied Engineering Research,V-10,I-2,PP-4487-4496,Y-2015

32. Jasmin M.,Optimization techniques for low power VLSI circuits,Middle - East Journal of Scientific Research,V-20,I-9,PP-1082-1087,Y-2014

33. Jasmin M., Vigneswaran T.,Fuzzy controller for error control of on Chip communication,2017 International Conference on Algorithms, Methodology, Models and Applications in Emerging Technologies, ICAMMAET 2017,V-2017-January,I-,PP-1-5,Y-2017

\section{AUTHORS PROFILE}

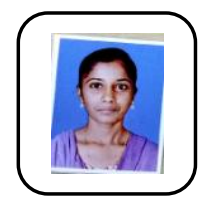

K.Premalatha, Student, Department of Management Studies, Bharath Institute of Higher Education and Research, Chennai, India

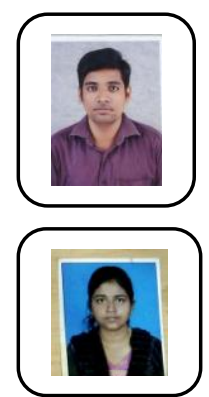

CS Gowtham, Associate Professor, Department of Management Studies, Bharath Institute of Higher Education and Research, Chennai, India

Ranjitha Devi, Student, Department of Management Studies, Bharath Institute of Higher Education and Research, Chennai, India 